\title{
Inheritance of Resistance to Zucchini Yellow Mosaic Virus in Watermelon
}

\author{
Nihat Guner \\ Sakata Seed America, Inc., Morgan Hill, CA 95037
}

Luis A. Rivera-Burgos ${ }^{1}$ and Todd C. Wehner

Department of Horticultural Science, North Carolina State University, Raleigh, NC 27695

Additional index words. Citrullus mucosospermus, genetics, single recessive gene, plant introduction

\begin{abstract}
Sources of resistance to the Zucchini yellow mosaic virus-Florida strain (ZYMVFL) have been identified within the Citrullus genus. Inheritance of resistance to ZYMVFL was studied in PI 595203 (Citrullus mucosospermus), a resistant watermelon accession. The $\mathrm{F}_{1}, \mathrm{~F}_{2}$, and $\mathrm{BC}_{1}$ progenies derived from the cross 'Calhoun Gray' $($ CHG) $\times$ PI 595203 and 'New Hampshire Midget' $($ NHM) $\times$ PI 595203 were used to study the inheritance of resistance to ZYMV-FL. Seedlings were inoculated with a severe isolate of ZYMV-FL at the first true leaf stage and rated weekly for at least 6 weeks on a scale of 1 to 9 on the basis of severity of viral symptoms. A single recessive gene (zymFL) was found to control the high level of resistance to ZYMV-FL in PI 595203.
\end{abstract}

Watermelon [Citrullus lanatus (Thunb.) Matsum. \& Nakai] is a major cucurbit crop that accounts for $7.5 \%$ of the world area devoted to vegetable crop production (FAO, 2015). In the United States, watermelon is used fresh as a dessert, or in salads. Major production states in the United States. are Florida, California, Texas, Georgia, and North Carolina (USDA, 2017). Production increased from 1.2 million $\mathrm{Mg}$ (metric tons) in 1987 to 5.1 million $\mathrm{Mg}$ in 2017, with a farm value of $\$ 579$ million (USDA, 2017).

Plant diseases incited by viruses are a major limiting factor in commercial watermelon production worldwide. More than 10 viruses are known to be a problem in watermelon field production (Ali et al., 2012; Wang et al., 2017). The major viruses affecting watermelon in the United States are Zucchini yellow mosaic virus (ZYMV), Papaya ringspot virus-watermelon strain (PRSV-W), and Watermelon mosaic virus (WMV). All three viruses are nonpersistently transmitted by several species of aphids, and mixed infections are common (Ali et al., 2012; Chen et al., 2008; Guner et al., 2018; Morata and Puigdomènech, 2017; Wehner et al., 2001). Chemical control of the vectors is not usually an efficient method of controlling the disease. Cultural controls such as treatment with mineral oil sprays and light-reflective surfaces, and cross-protection with weak ZYMV isolates showed limited effectiveness and required additional input costs. Therefore, genetic resistance remains the simplest, most effective, and most efficient means of limiting losses to these diseases (Ali et al., 2012;

Received for publication 12 Mar. 2018. Accepted for publication 26 Apr. 2018.

${ }^{1}$ Corresponding author. E-mail: lariver2@ncsu. edu.
Levi et al., 2016a; Nagendran et al., 2017; Yu et al., 2011).

ZYMV was first described in 1981 in squash grown in northern Italy and France, where it was named Muskmelon yellow stunt virus (Lisa and Dellvalle, 1981; Tiwari and Rao, 2014). ZYMV infects all the agriculturally important species of Cucurbitaceae family (e.g., C. lanatus, Cucumis sativus, Cucumis melo, and Cucurbita spp.) and is considered the most destructive virus in watermelon production worldwide (Nagendran et al., 2017; Provvidenti, 1991). ZYMV is transmitted in a nonpersistent manner by several aphid species (e.g., Aphis gossypii Glover) and easily transmitted mechanically. In areas where cucurbit crops are not grown continuously, the virus overwinters on wild species. Natural infection appears to be limited to species of the Cucurbitaceae, but members of 11 families of dicotyledons are considered diagnostic hosts (Tiwari and Rao, 2014).

ZYMV, with flexuous particles $\approx 750 \mathrm{~nm}$ long containing a single strand of RNA, belongs to the genus Potyvirus in the family Potyviridae (Romay et al., 2014; Tiwari and Rao, 2014). At least 25 strains of ZYMV have been identified (Desbiez and Lecoq, 1997). Provvidenti et al. (1984) reported the occurrence of Connecticut (CT) and Florida (FL) strains of ZYMV, with the FL strain occurring more widely in the United States. In the 1990s, Provvidenti also identified a new ZYMV strain infecting cucurbit fields around Beijing, China, Zucchini yellow mosaic virus-China strain (ZYMV-CH). Plants infected with any of the ZYMV strains reduce their photosynthetic capacity and display stunted growth, deformed fruit, and early mortality (Guner and Wehner, 2008). Symptoms of severe ZYMV infection in cucurbit crops include yellow mosaic, stunting, blistering, and laminar reduction on leaves, and fruit remaining small, developing knobby areas, greatly malformed, and mottled (Nagendran et al., 2017).

Researchers have screened the germplasm resources of several cucurbit species for resistance to ZYMV, and the inheritance of the resistance has been reported in cucumber $(C$. sativus), melon (C. melo), and squash (Cucurbita spp.). ZYMV resistance is controlled by a single recessive gene in cucumber (Cardoso et al., 2010; Kabelka and Grumet, 1997), a single dominant gene in melon (Park et al., 2004; Pitrat and Lecoq, 1984), and a single dominant gene in squash (Paris and Brown, 2005).

The watermelon germplasm collection has been screened for resistance to ZYMV, and several resistant PI accessions have been identified (Boyhan et al., 1992; Guner, 2004; Provvidenti, 1991). Provvidenti (1991) reported ZYMV resistance in four PI accessions of watermelon from Zimbabwe (PI 482322, PI 482299, PI 482261, and PI 482308). The ZYMV resistance in the four resistant watermelon PI accessions appeared to be specific to the Florida strain (ZYMVFL). Some accessions of egusi watermelon (C. mucosospermus) originating in Nigeria (PI 494528 and PI 494532) were reported resistant to ZYMV, and the resistance was not specific to the virus strain. However, the resistance was temperature dependent and was expressed best in warm or hot climates (Provvidenti, 1986). Provvidenti (1991) reported that resistance in PI 482261 (Citrullus amarus) was conferred by a single recessive gene, which he named zym. Boyhan et al. (1992) reported additional sources of resistance to ZYMV in PI 386026, PI 386025 (both Citrullus colocynthis), and the egusi PI 595203 (C. mucosospermus). They also confirmed ZYMV resistance in PI 482261 and PI 494528.

Guner (2004) screened 1613 PI accessions along with 41 watermelon cultivars for resistance to ZYMV. A high level of resistance to ZYMV was found in several PI accessions. These new resistant PI accessions were PI 386019, PI 490377, PI 596662, PI 485580, PI 560016, PI 494528, PI 386016, PI 482276, and PI 595201. The study also confirmed the resistance of PI 595203 (egusi), PI 386025, PI 386026, and PI 494528. However, the resistance of PI 482322, PI 482299, PI 482261, and PI 482308 as reported by Provvidenti (1991) was not confirmed. Those PI accessions had only moderate resistance to the Florida strain (ZYMV-FL) used in the study of Guner (2004).

Although it was reported that the inheritance of the resistance to $\mathrm{ZYMV}-\mathrm{CH}$ in PI 595203 is controlled by a single recessive gene (Xu et al., 2004), there is not a formal report on the inheritance of the resistance to ZYMV-FL in PI 595203. Whether the ZYMV-FL and ZYMV-CH strains are the same has not been determined (Harris et al., 2009; Levi and Ling, 2017; Levi et al., 2016b; Ling et al., 2009). Therefore, the 
objective of this study was to determine the inheritance of ZYMV-FL resistance in PI 595203 (C. mucosospermus), an egusi watermelon type that was also identified as the source of resistance to ZYMV-CH strain, a geographically distant isolate.

\section{Materials and Methods}

Plant material. The parental lines used in this study were CHG and NHM, highly susceptible to ZYMV, and an egusi accession (PI 595203), our best source of resistance. Two families were developed by crossing PI 595203 with CHG and NHM. All crosses were made using hand-pollination in the greenhouse. Six generations (susceptible parent, resistant parent, $F_{1}, F_{2}$, backcross to the susceptible parent, and backcross to the resistant parent) were developed for the study of inheritance of resistance. For each of the two crosses, 180 plants were tested: $5 \mathrm{P}_{\mathrm{s}}, 5 \mathrm{P}_{\mathrm{r}}$, $30 \mathrm{BC}_{1} \mathrm{P}_{\mathrm{s}}, 30 \mathrm{BC}_{1} \mathrm{P}_{\mathrm{r}}, 10 \mathrm{~F}_{1}$, and $100 \mathrm{~F}_{2}$ plants were used to test the inheritance from each cross.

Planting and management. All experiments were performed in the greenhouse of the Department of Plant Pathology at North Carolina State University in Raleigh, NC. Greenhouse temperatures ranged from 23 to $43{ }^{\circ} \mathrm{C}$ (day) and from 12 to $24{ }^{\circ} \mathrm{C}$ (night). We seeded directly in plastic pots $(100 \times 100 \mathrm{~mm}$ size, 600-mL volume) filled with a soilless mix (Canadian sphagnum moss, perlite, vermiculite, and processed pine bark). We planted two seeds per pot and thinned to one to ensure a uniform experiment (Gusmini et al., 2017).

Inoculum preparation. The virus isolate was obtained from E. Hiebert, University of Florida, Gainesville. The Florida strain of ZYMV was used to study the inheritance of resistance. Isolate 2088, a severe isolate of ZYMV-FL, was described by Wisler et al. (1995). The ZYMV isolate used for our research was a subculture of isolate 2088, maintained on 'Gray Zucchini' squash (Cucurbita pepo L.) from Seminis Vegetable Seeds (Woodland, CA). The inoculum was prepared by grinding infected 'Gray

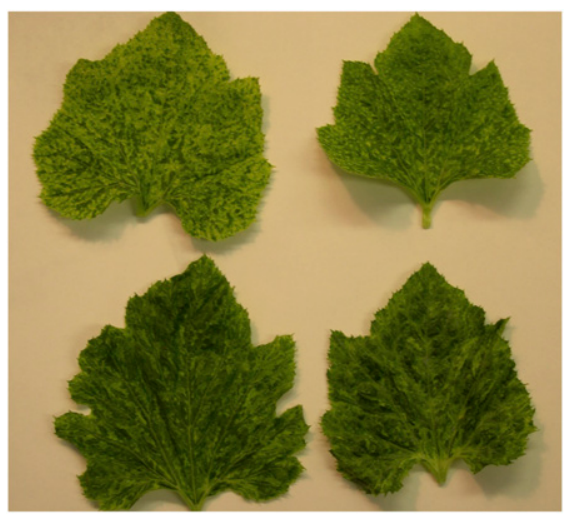

Fig. 1. Infected 'Gray Zucchini' leaves used to maintain and increase inoculum for the inheritance study.
Zucchini' leaves using a mortar and pestle in $0.02 \mathrm{M}$ phosphate buffer (Fig. 1), $\mathrm{pH}$ 7.0. The leaf to buffer ratio was $1: 5$ ( $1 \mathrm{~g}$ infected leaf to $5 \mathrm{~mL}$ buffer).

To maintain the ZYMV-FL isolate and increase the inoculum, we used the rub method (Guner et al., 2002). Squash plants were inoculated by dusting one leaf on each 3-week-old plant with 800-mesh carborundum and then applying the inoculum to the leaf with a pestle, which was rotated in a circular motion eight to 10 times as if painting the leaf with inoculum. After inoculation, carborundum was rinsed off the leaves to improve light interception, and the plants were maintained in aphid-proof cages. All 'Gray Zucchini' plants were seeded in Metro-Mix 200 (Scotts-Sierra Horticultural

Table 1. Single locus goodness-of-fit test $(P<0.05)$ for resistance to Zucchini yellow mosaic virus-Florida strain in two crosses of watermelon.

\begin{tabular}{|c|c|c|c|c|c|}
\hline Parent/Progeny & No. susceptible & No. resistant & Expected ratio ${ }^{z}$ & $\chi^{2}$ & $P$ value \\
\hline \multicolumn{6}{|c|}{ 'Calhoun Gray' (susceptible) × PI 595203 (resistant) } \\
\hline $\mathrm{P}_{\mathrm{S}}^{\mathrm{y}}$ & 5 & 0 & & & \\
\hline $\mathrm{P}_{\mathrm{r}}^{\mathrm{x}}$ & 0 & 5 & & & \\
\hline$F_{1}$ & 10 & 0 & & & \\
\hline $\mathrm{BC}_{1} \mathrm{P}_{\mathrm{s}}$ & 30 & 0 & & & \\
\hline $\mathrm{BC}_{1} \mathrm{P}_{\mathrm{r}}$ & 16 & 14 & $1: 1$ & 0.13 & 0.72 \\
\hline $\mathrm{F}_{2}$ & 70 & 26 & $3: 1$ & 0.22 & 0.64 \\
\hline \multicolumn{6}{|c|}{ 'New Hampshire Midget' (susceptible) $\times$ PI 595203 (resistant) } \\
\hline $\mathrm{P}_{\mathrm{s}}^{\mathrm{y}}$ & 5 & 0 & & & \\
\hline $\mathrm{P}_{\mathrm{r}}^{\mathrm{x}}$ & 0 & 5 & & & \\
\hline $\mathrm{F}_{1}$ & 10 & 0 & & & \\
\hline $\mathrm{BC}_{1} \mathrm{P}_{\mathrm{s}}$ & 30 & 0 & & & \\
\hline $\mathrm{BC}_{1} \mathrm{P}_{\mathrm{r}}$ & 15 & 15 & $1: 1$ & 0.00 & 1.00 \\
\hline $\mathrm{F}_{2}$ & 76 & 21 & $3: 1$ & 0.05 & 0.82 \\
\hline \multicolumn{6}{|c|}{ Susceptible $\times$ resistant crosses, pooled } \\
\hline $\mathrm{P}_{\mathrm{S}}^{\mathrm{y}}$ & 10 & 0 & & & \\
\hline $\mathrm{P}_{\mathrm{r}}^{\mathrm{x}}$ & 0 & 10 & & & \\
\hline $\mathrm{F}_{1}$ & 20 & 0 & & & \\
\hline $\mathrm{BC}_{1} \mathrm{P}_{\mathrm{s}}$ & 60 & 0 & & & \\
\hline $\mathrm{BC}_{1} \mathrm{P}_{\mathrm{s}}$ & 31 & 29 & $1: 1$ & 0.07 & 0.80 \\
\hline $\mathrm{F}_{2}$ & 146 & 50 & $3: 1$ & 0.03 & 0.87 \\
\hline
\end{tabular}

${ }^{{ }^{2}}$ Expected was the hypothesized segregation ratio for single-gene inheritance.

${ }^{\mathrm{y}} \mathrm{P}_{\mathrm{s}}$ was the susceptible parent.

${ }^{\mathrm{x}} \mathrm{P}_{\mathrm{r}}$ was the resistant parent.

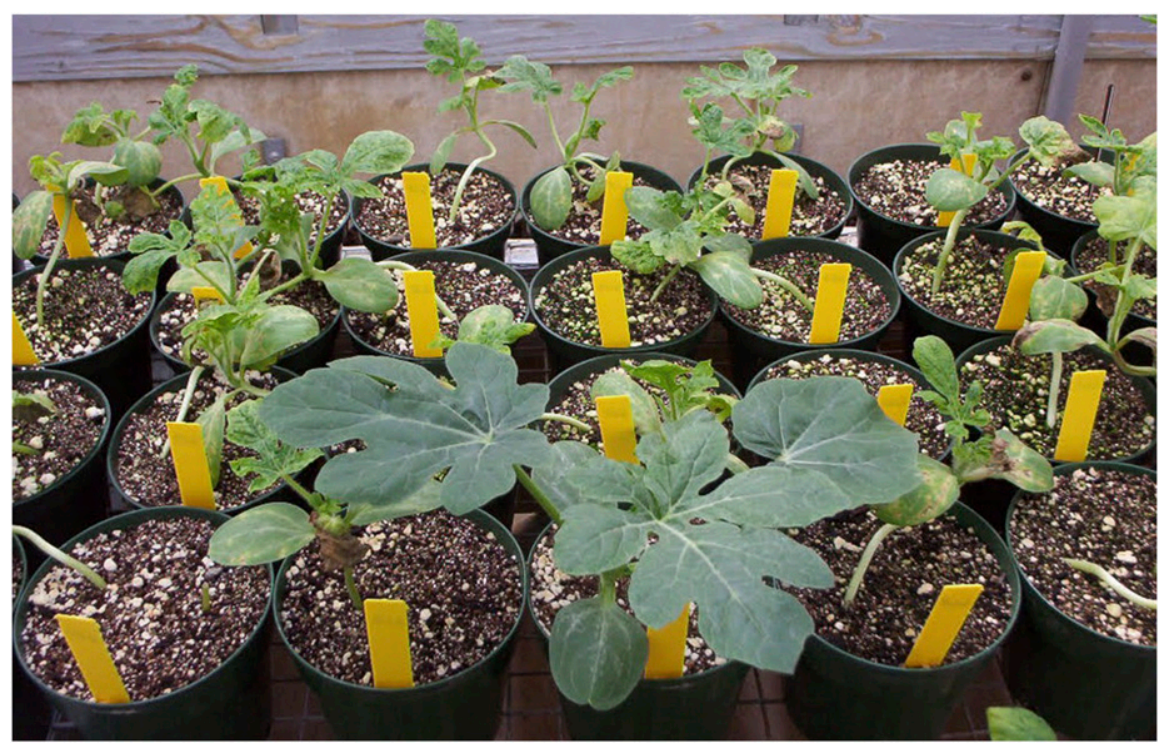

Fig. 2. $F_{2}$ population segregating three susceptible: one resistant ratio for resistance to Zucchini yellow mosaic virus.
Products Company, Marysville, $\mathrm{OH}$ ) in $160 \mathrm{~mm}$ diameter (1550 $\mathrm{mL}$ volume) clay pots. Plants were fertilized weekly with $150 \mathrm{mg} \cdot \mathrm{kg}^{-1}$ Peters Professional 20-20-20 $\mathrm{N}-\mathrm{P}-\mathrm{K}$ (Scotts-Sierra Horticultural Products Company).

Inoculation and data collection. The previously described inoculation procedure to maintain the ZYMV-FL isolate and increase in squash plants was also used for the inheritance study (Guner et al., 2002). Plants were inoculated at the first true leaf starting 2 weeks after inoculation. Plants were rated using a scale of 0 to 9 , where $0=$ none, $1=$ trace of symptoms, $2=$ tendrils absent, 3 = tendrils absent, slightly stunted growth, $4=$ mosaic patches, necrotic spots on 
leaves, or both, $5=$ leaves near apical meristem deformed, meristem yellow, and reduced in size, $6=$ apical meristem withered and brown, $7=$ apical meristem dead with more basal leaves dying, $8=$ most leaves dead, main stem green/yellow, $9=$ plant dead (Guner et al., 2002). After the last rating, plants were tested by enzyme-linked immunosorbent assay (ELISA) (Agdia Incorporated, Elkhart, IN) to determine the presence of the virus in the leaf tissue. Leaf tissue used for testing was sampled from the top five leaves of the plant. Plants were classified as resistant or susceptible based on their rank relative to the estimated mean value of the disease severity scale (5.0) and ELISA test results. Plants that did not have the virus in their system and had an average rating $<5.0$ were considered resistant, and plants with the virus in their system and an average rating $>5.0$ were considered susceptible (Strange et al., 2002).

Statistical analysis. The chi square tests for goodness of fit $(P<0.05)$ and homogeneity were used to examine segregation ratios (susceptible:resistant) for each $\mathrm{F}_{2}$ and $\mathrm{BC}_{1} \mathrm{P}_{\mathrm{r}}$ progeny with the SAS statistical package (SAS Institute, Cary, NC) and the SASGene 1.2 program (Liu et al., 1997).

Yates' correction was used for those chi square tests where counts were $\leq 5$ for any class in the ratio. However, the correction made no difference to our conclusions, so we presented the data uncorrected for ease of understanding and to avoid the tendency of Yates' method to overcorrect (Haviland, 1990).

\section{Results and Discussion}

Zucchini yellow mosaic virus (ZYMV) is one of the most destructive nonpersistently aphid-borne potyvirus infecting watermelon fields in the United States (Desbiez et al., 2003). There are nongenetic control methods, such as the use of insecticides to eliminate virus vectors, herbicides to remove alternate host (weeds) for the virus, removing old crop plants quickly, and avoiding overlapping or side-by-side plantings. In this study, we focused on the genetic approach to minimize losses caused by ZYMV (Coutts et al., 2011; Guner and Wehner, 2008) using resistance to ZYMV-FL in PI 595203.

Segregation ratios for resistance to the Florida strain ZYMV in the $\mathrm{F}_{1}, \mathrm{~F}_{2}$, and $\mathrm{BC}_{1}$ populations developed from crossing one susceptible and one resistant parent were similar to the previously published results by Provvidenti (1991) who also reported a single recessive gene for resistance to the Florida strain of ZYMV using a different accession, PI 482261. Guner et al. (2004) also tested PI 482261 for resistance to ZYMV using the same isolate (FL) as in this study and found no resistance in that accession. Probably, the isolate of ZYMV-FL used in our study was more virulent than the one used by Provvidenti (1991). In 2004, Xu et al. studied the inheritance of ZYMV-CH in PI 595203. They reported that resistance to
ZYMV-CH was conferred by a single recessive gene, for which the symbol zym- $\mathrm{CH}$ was suggested. The PI 595203 is also resistant to PRSV-W and WMV. Thus, PI 595203 is an important source of resistance for those developing cultivars of watermelon with resistance to multiple viruses (Guner and Wehner, 2008; Strange et al., 2002; Xu et al., 2004).

In the $\mathrm{F}_{1}$ progenies, all plants developed severe systemic symptoms of ZYMV, indicating that resistance in PI 595203 was inherited in a recessive manner (Table 1). This condition was confirmed by the reaction in the $F_{2}$ progenies as shown in Fig. 2, which segregated in a ratio of three susceptible to one resistant $\left(\chi^{2}=0.22 ; P\right.$ value $=0.64 ; \chi^{2}=$ $0.05 ; P$ value $=0.82)$. A segregation of one susceptible to one resistant was obtained in plants of the backcross progenies to the resistant parents $\left(\chi^{2}=0.13 ; P\right.$ value $=0.72$; $\chi^{2}=0.00 ; P$ value $\left.=1.00\right)$. Progenies of the backcross to the susceptible parents were all susceptible (Table 1). When data from both crosses $(\mathrm{CHG} \times$ PI 595203 and $\mathrm{NHM} \times \mathrm{PI}$ 595203 ) were pooled, the $F_{2}$ progeny segregated to 146 susceptible and to 50 resistant $\left(\chi^{2}=0.03 ; P\right.$ value $\left.=0.87\right)$, and the $\mathrm{BC}_{1} \mathrm{P}_{\mathrm{r}}$ progeny segregated to 31 susceptible to 29 resistant $\left(\chi^{2}=0.07 ; P\right.$ value $\left.=0.80\right)$. Our results suggest that the high level of resistance to ZYMV-FL observed in PI 595203 is controlled by a single recessive gene, $z y m$-FL (Guner, 2004; Wehner, 2012).

\section{Literature Cited}

Ali, A., O. Mohammad, and A. Khattab. 2012. Distribution of viruses infecting cucurbit crops and isolation of potential new virus-like sequences from weeds in Oklahoma. Plant Dis. 96:243-248

Boyhan, G., J.D. Norton, B.J. Jacobsen, and B.R. Abrahams. 1992. Evaluation of watermelon and related germplasm for resistance to $\mathrm{Zuc}$ chini yellow mosaic virus. Plant Dis. 76:251252.

Cardoso, A.I.I., M.A. Pavan, R. Krause Sakate, and K. Fattori. 2010. Inheritance of cucumber tolerance to Zucchini yellow mosaic virus. J. Plant Pathol. 92:245-248.

Chen, K-C., C-H. Chiang, J. A. Raja, F-L. Liu, C-H. Tai, and S-D. Yeh. 2008. A single amino acid of NIaPro of Papaya ringspot virus determines host specificity for infection of papaya. Mol. Plant Microbe Interact. 21:1046-1057.

Coutts, B.A., M.A. Kehoe, and R.A.C. Jones. 2011. Minimising losses caused by Zucchini yellow mosaic virus in vegetable cucurbit crops in tropical, sub-tropical and mediterranean environments through cultural methods and host resistance. Virus Res. 159:141-160.

Desbiez, C., A. Gal-On, M. Girard, C. WipfScheibel, and H. Lecoq. 2003. Increase in Zucchini yellow mosaic virus symptom severity in tolerant zucchini cultivars is related to a point mutation in $\mathrm{P} 3$ protein and is associated with a loss of relative fitness on susceptible plants. Phytopathology 93:1478-1484.

Desbiez, C. and H. Lecoq. 1997. Zucchini yellow mosaic virus. Plant Pathol. 46:809-829.

FAO. 2015. FAO statistical pocketbook. FAO Statistic Division, Rome, Italy.

Guner, N. 2004. Papaya ringspot virus watermelon strain and Zucchini yellow mosaic virus resistance in watermelon. North Carolina State Univ., Raleigh, PhD Diss.

Guner, N., Z. Pesic-VanEsbroeck, L.A. RiveraBurgos, and T.C. Wehner. 2018. Inheritance of resistance to Papaya ringspot virus-watermelon strain in watermelon. HortScience 53:624-627.

Guner, N., E.B. Strange, T.C. Wehner, and Z. Pesic-VanEsbroeck. 2002. Methods for screening watermelon for resistance to Papaya ringspot virus type-W. Scientia Hort. 94:297-307.

Guner, N. and T.C. Wehner. 2008. Overview of potyvirus resistance in watermelon. In: M. Pitrat (ed.). Cucurbitaceae 2008: Proc. of the IX $^{\text {th }}$ EUCARPIA Meeting on Genetics and Breeding of Cucurbitaceae. Avignon, France. p. $445-452$.

Gusmini, G., L.A. Rivera-Burgos, and T.C. Wehner. 2017. Inheritance of resistance to gummy stem blight in watermelon. HortScience 52:1477-1482.

Harris, K.R., K. Ling, W.P. Wechter, and A. Levi. 2009. Identification and utility of markers linked to the Zucchini yellow mosaic virus resistance gene in watermelon. J. Amer. Soc. Hort. Sci. 134:529-534.

Haviland, M.G. 1990. Yate's correction for continuity and the analysis of $2 \times 2$ contingency tables. Stat. Med. 9:363-367.

Kabelka, E. and R. Grumet. 1997. Inheritance of resistance to the Moroccan Watermelon mosaic virus in the cucumber line TMG-1 and cosegregation with Zucchini yellow mosaic virus resistance. Euphytica 95:237-242.

Levi, A., J. Coffey, L. Massey, N. Guner, E. Oren, Y. Tadmor, and K.S. Ling. 2016a. Resistance to Papaya ringspot virus-watermelon strain (PRSV-W) in the desert watermelon Citrullus colocynthis. HortScience 51:4-7.

Levi, A., K.R. Harris-Shultz, and K-S. Ling. 2016b. USVL-370, a Zucchini yellow mosaic virusresistant watermelon breeding line. HortScience 51:107-109.

Levi, A. and K-S. Ling. 2017. USVL-380, a Zucchini yellow mosaic virus-resistant watermelon breeding line. HortScience 52:1448-1450.

Ling, K-S., K.R. Harris, J.D. Meyer, A. Levi, N. Guner, T.C. Wehner, A. Bendahmane, and M.J. Havey. 2009. Non-synonymous single nucleotide polymorphisms in the watermelon eIF4E gene are closely associated with resistance to Zucchini yellow mosaic virus. Theor. Appl. Genet. 120:191-200

Lisa, V. and G. Dellvalle. 1981. Characterization of two potyvirus from zucchini squash. Phytopathology 100:279-286.

Liu, J.S., T.C. Wehner, and S.B. Donaghy. 1997. SASGENE: A SAS computer program for genetic analysis of gene segregation and linkage. J. Hered. 88:253-254.

Morata, J. and P. Puigdomènech. 2017. Variability among Cucurbitaceae species (melon, cucumber and watermelon) in a genomic region containing a cluster of NBS-LRR genes. BMC Genomics 18:1-7.

Nagendran, K., S. Mohankumar, R. Aravintharaj, C.G. Balaji, S.K. Manoranjitham, A.K. Singh, A.B. Rai, B. Singh, and G. Karthikeyan. 2017. The occurrence and distribution of major viruses infecting cucurbits in Tamil Nadu state, India. Crop Protection 99:10-16.

Paris, H.S. and R.N. Brown. 2005. The genes of pumpkin and squash. HortScience 40:1620 1630

Park, Y., N. Katzir, Y. Brotman, J. King, F. Bertrand, and M. Havey. 2004. Comparative mapping of ZYMV resistances in cucumber (Cucumis sativus L.) and melon (Cucumis melo L.). Theor. Appl. Genet. 109:707-712. 
Pitrat, M. and H. Lecoq. 1984. Inheritance of Zucchini yellow mosaic virus resistance in Cucumis melo L. Euphytica 33:57-61.

Provvidenti, R. 1986. Reactions of PI accessions of Citrullus colocynthis to Zucchini yellow mosaic virus and other viruses. Rpt. Cucurbit Genet. Coop. 9:82-83.

Provvidenti, R. 1991. Inheritance of resistance to Zucchini yellow mosaic virus and Watermelon mosaic virus in watermelon. HortScience 26: 407-408.

Provvidenti, R., D. Gonsalves, and H.S. Humaydan. 1984. Occurrence of Zucchini yellow mosaic virus in cucurbits from Connecticut, New York, Florida and California. Plant Dis. 68: 443-446.

Romay, G., H. Lecoq, and C. Desbiez. 2014. Cucurbit crops and their viral diseases in Latin America and the Caribbean islands: A review. J. Plant Pathol. 96:227-242.
Strange, E., N. Guner, Z. Pesic-VanEsbroeckb, and T. Wehner. 2002. Screening the watermelon germplasm collection for resistance to Papaya ringspot virus type-W. Crop Sci. 42:1324-1330.

Tiwari, A.K. and G.P. Rao. 2014. Viruses infecting Cucurbita pepo: Current status and management, p. 357-371. In: R.N. Kharwar, R.S Upadhyay, N.K. Dubey, and R. Raghuwansh (eds.). Microbial diversity and biotechnology in food security. Springer India, New Delhi, India.

USDA. 2017. Agricultural statistics. Washington, D.C.

Wang, D., G. Li, and S.S. Du. 2017. Occurrence of viruses infecting melon in Xinjiang of China and molecular characterization of Watermelon mosaic virus isolates. Eur. J. Plant Pathol. 147:919-931.

Wehner, T.C. 2012. Watermelon gene list. Rpt. Cucurbit Genet. Coop. 36:40-64.
Wehner, T.C., N.V. Shetty, and G.W. Elmstrom. 2001. Breeding and seed production, p. 27-73. In: D.N. Maynard (ed.). Watermelon: Characteristics, production, and marketing. ASHS Press, Alexandria, VA

Wisler, G.C., D.E. Purcifull, and E. Hiebert. 1995 Characterization of the P1 protein and coding region of the Zucchini yellow mosaic virus. J. of General Virology 76:37-45.

$\mathrm{Xu}$, Y., D. Kang, Z. Shi, H. Shen, and T.C. Wehner. 2004. Inheritance of resistance to Zucchini yellow mosaic virus and Watermelon mosaic virus in watermelon. J. Hered. 95:498-502.

Yu, T.A., C.H. Chiang, H.W. Wu, C.M. Li, C.F. Yang, J.H. Chen, Y.W. Chen, and S.D. Yeh. 2011. Generation of transgenic watermelon resistant to Zucchini yellow mosaic virus and Papaya ringspot virus type W. Plant Cell Rpt. 30:359-371. 